\title{
Special issue on smart tourism: convergence of information technologies, experiences, and theories
}

\author{
Ulrike Gretzel $^{1} \cdot$ Chulmo Koo $^{2} \cdot$ Marianna Sigala $^{3} \cdot$ Zheng Xiang $^{4}$
}

Published online: 14 July 2015

(C) Institute of Information Management, University of St. Gallen 2015

The notion of smart tourism has been gaining currency recently, particularly as a strategic tool for tourism development. For instance, under the general framework of smart city initiatives, the European Commission (2015) has identified travel information and communication as one of the strategic objectives for improving human mobility and transportation. In emerging economies like China smart tourism is becoming an integral part of the national policy for economic development and overall improvement of service quality with the aide of information technology (CNTA 2015). Generally speaking, smart tourism aims to develop information and communication infrastructure and capabilities in order to improve management/ governance, facilitate service/product innovation, enhance the tourist experience, and, ultimately, improve the competitiveness of tourism firms and destinations (Gretzel et al. 2015; Hunter et al. 2015; Koo et al. 2015). Considering tourism is

Chulmo Koo

helmetgu@khu.ac.kr

Ulrike Gretzel

u.gretzel@business.uq.edu.au

Marianna Sigala

m.sigala@aegean.gr

Zheng Xiang

philxz@vt.edu

1 UQ Business School, University of Queensland, Sir Fred Schonell Dr., St. Lucia, QLD 4072, Australia

2 College of Hotel and Tourism Management, Kyung Hee University, Kyung Hee Dearo 26, Dongdeamun-Gu, Seoul 130-701, South Korea

3 School of Management, Business School, University of South Australia, 55-57 North Terrace, 5000 Adelaide, SA, Australia

4 Department of Hospitality and Tourism Management, Pamplin College of Business, Virginia Tech, 295 West Campus Drive, Blacksburg, VA 24061, USA an important, and in many cases even primary, sector in national economies, smart tourism seems to offer a promising direction for sustainable tourism development and has the potential to impact tourist destinations and their representations in electronic markets at different levels.

The notion of smart tourism was born against the backdrop of the recent development and diffusion of information technology that offers new modalities of communication, new ways for data collection, analysis and exchanges, and thus, new opportunities for value creation and management (Lazer et al. 2009). In the past decade or so, we have seen incredible growth of search technologies, online travel distribution channels, virtual tourism communities, and numerous forms of social media that allow travelers to make more convenient and smarter decisions (Sigala et al. 2012; Xiang et al. 2014). These technologies and systems are directly or indirectly connected to, or have impact on, various computerized reservation systems, which have long been integrated by the travel and tourism industry (Alt and Klein 2011; Kärcher 1995; Mitev 1999). The widespread adoption of mobile technology, especially the smartphone, seems to have further accelerated this trend with the convergence of information search, communication, entertainment, social networking as well as mobility-related functionalities to assist travelers on the go (Wang and Xiang 2012). Furthermore, the growing capabilities of embedding and connecting a variety of RFID tags, sensors and mobile devices into our physical environment seems to lead to a more optimistic view that now is the time for technological innovations in terms of co-creation processes and the management of tourist experiences (Atzori et al. 2010; Taafe 2014).

While it is a phenomenon of growing significance, scholarly work on smart tourism is lacking, both conceptually and empirically. In response to this emerging need, the journal of Electronic Markets presents a special issue that disseminates 
the latest research findings related to smart tourism. The first article, i.e., "Smart Tourism: Foundations and Developments", serves as a position paper addressing the conceptual and theoretical foundations of smart tourism. This paper first describes the technological foundations including topics like what technologies facilitate smart tourism and what technological developments will continue to push the smart tourism frontier. Then, it outlines the business aspects of smart tourism including the underlying business models as well as the business approaches to support smart tourism. Finally, it discusses opportunities and limitations regarding the implementation of smart tourism.

The next papers are empirically based. The second paper, entitled "The Application and Impact of Gamification Funware on Trip Planning and Experiences: The Case of TripAdvisor's Funware" (Sigala 2015), addresses the employment of the fun factor in the adoption and use of technology for the achievement of business benefits and customer value. Specifically, it presents a model that delineates the impact of gamification in a specific tourism context in which TripAdvisor uses its funware to motivate users to engage with its website and to enhance the travelers' online experiences and trip planning processes. The third paper, entitled "How does Hotel Attribute Importance Vary among Different Travelers? An Exploratory Case Study Based on a Conjoint Analysis Approach" (Rhee and Yang 2015), develops a novel approach based upon TripAdvisor's online review data. The findings show that certain attributes of the hotel product contribute more strongly than others to overall ratings of the hotel. The fourth paper, entitled "Mineable or Messy? Assessing the Quality of Macro-level Tourism Information Derived from Social Media" (Tilly et al. 2015), investigates the quality of macro-level information on the spatio-temporal distribution of tourism derived from online travel reviews in terms of completeness (how many countries covered), timeliness (how long until information is accessible), and accuracy (how accurately is the global distribution of online travel reviews associated with figures from traditional sources). Finally, the paper "Smart technologies for personalized experiences: a case study in the hospitality domain" (Neuhofer et al. 2015) introduces how smart mobile technologies can facilitate personalized experiences in the context of the hospitality industry. This paper identifies the requirements of smart technologies for experience creation, including information aggregation, ubiquitous mobile connectedness and real time synchronization and highlights how smart technology integration can lead to two distinct levels of personalized tourism experiences. These four papers explore, in different ways, the value of information and communication technology in our understanding of user/consumer experiences and provide invaluable implications for smart tourism development.

While this collection of articles is by no means a comprehensive coverage of topics related to smart tourism, we hope this special issue offers a stepping stone for researchers and practitioners to consider smart tourism as an increasingly important yet challenging problem as well as a rich domain for future research. To conclude, we thank the authors for choosing this special issue as the outlet for publishing their research findings. We would also like to thank a team of international reviewers who devoted their time to rigorously reviewing the submissions and provided critical and constructive comments. Last but certainly not least, we would like to thank the editor(s) of Electronic Markets for supporting this project. It is hoped that this special issue will stimulate conversations and lead to more valuable insights into smart tourism.

\section{References}

Alt, R., \& Klein, S. (2011). Twenty years of electronic markets researchlooking backwards towards the future. Electronic Markets, 21(1), 41-51.

Atzori, L., Iera, A., \& Morabito, G. (2010). The internet of things: a survey. Computer Networks, 54(15), 2787-2805.

CNTA (2015). Directives on smart tourism development Available at http://www.cnta.gov.cn/html/2015-1/2015-1-12-10-2-70814.html.

European Commission (2015). European Initiative on Smart Cities. Available at http://setis.ec.europa.eu/set-plan-implementation/ technology-roadmaps/european-initiative-smart-cities.

Gretzel, U., Werthner, H., Koo, C., \& Lamsfus, C. (2015). Conceptual foundations for understanding smart tourism ecosystems. Computers in Human Behavior, forthcoming.

Hunter, W. C., Chung, N., Gretzel, U., \& Koo, C. (2015). Constructivist research in smart tourism. Asia Pacific Journal of Information Systems, 25(1), 105-120.

Lazer, D., Pentland, A. S., Adamic, L., Aral, S., Barabasi, A. L., Brewer, D., \& Van Alstyne, M. (2009). Life in the network: the coming age of computational social science. Science (New York, NY), 323(5915), 721

Kärcher, K. (1995). The emergence of electronic market systems in the European tour operator business. Electronic Markets, 5(1), 10-11.

Koo, C., Gretzel, U., Hunter, W. C., \& Chung, N. (2015). The role of IT in tourism. Asia Pacific Journal of Information Systems, 25(1), 99104.

Mitev, N. N. (1999). Electronic markets in transport: Comparing the globalization of air and rail computerized reservation systems. Electronic Markets, 9(4), 215-225.

Neuhofer, B., Buhalis, D., \& Ladkin, A. (2015). Smart technologies for personalized experiences: a case study in the hospitality domain. Electronic Markets, 25(3). doi:10.1007/s12525-015-0182-1.

Rhee, H. T., \& Yang, S.-B. (2015). How does hotel attribute importance vary among different travelers? An exploratory case study based on a conjoint analysis. Electronic Markets, 25(3). doi:10.1007/s12525014-0161-y.

Sigala, M. (2015). The application and impact of gamification funware on trip planning and experiences: the case of TripAdvisor's funware. Electronic Markets, 25(3). doi:10.1007/s12525-014-0179-1.

Sigala, M., Christou, E. \& Gretzel, U. (2012). Web 2.0 in Travel, Tourism and Hospitality: theory, practice and cases. Ashgate Publishers.

Taafe, J. (2014). Europe's Cities Get Smarter on Tourism Available at http://newsroom.cisco.com/press-release-content?type= webcontent\&articleId=1488545.

Tilly, R., Fischbach, K., \& Schoder, D. (2015). Mineable or messy? Assessing the quality of macro-level tourism information derived from social media. Electronic Markets, 25(3). doi:10.1007/s12525015-0181-2. 
Wang, D., \& Xiang, Z. (2012). The new landscape of travel: A comprehensive analysis of Smartphone Apps. In Information and Communication Technologies in Tourism 2012 (pp. 308-319). Springer Vienna.
Xiang, Z., Wang, D., O’Leary, J. T., \& Fesenmaier, D. R. (2014). Adapting to the internet: trends in travelers' use of the web for trip planning. Journal of Travel Research In press. doi:10.1177/ 0047287514522883 . 